\title{
Relationship between antipsychotic medication, obesity and cognitive functions
}

\author{
Urszula Łopuszańska ${ }^{1} \mathrm{ABCDEF}$, Marta Makara-Studzińska ${ }^{2} \mathrm{AD}$ \\ ${ }^{1}$ Department of Applied Psychology, Medical University of Lublin, Poland \\ ${ }^{2}$ Department of Developmental and Health Psychology, Jagiellonian University - Collegium Medicum, Cracow
}

\section{Abstract}

Introduction: The purpose of this study was to examine whether the combination of atypical and typical antipsychotic medications is related with metabolism and cognitive functions in the same manner and degree as taking medications of one kind only, i.e. atypical or typical.

Material and methods: The participants of the study comprised of 91 adults with diagnosed mental illness (F-20-F69). The participants were divided into groups on the basis of the kind of administered medications: T+A (typical and atypical medications), A (atypical medications), T (typical medications), P (antidepressants, sedatives, normothymic/antiepileptic drugs). In the study, Short Test of Mental Status (STMS), Verbal Fluency Test (VFT), Rey Auditory Verbal Learning Test (RAVLT) were used for the purpose of examining cognitive functions.

Results: The kind of antipsychotic medications taken by the patients did not differentiate the group in relation to BMI ( $<<0.13$ ), nor in relation to the level of general cognitive function $(\mathrm{p}<0.72)$ or verbal fluency $(\mathrm{p}<0.34)$. Both atypical antipsychotic m edications and the combination of atypical and typical medications were related to the occurrence of abdominal obesity ( $<<0.01$ ). An increase in waist circumference decreased an ability of abstract reasoning $(\mathrm{p}<0.005)$. When it comes to the body mass index, waist circu mference negatively correlated with the delayed memory $(\mathrm{p}<0.03, \mathrm{p}<0.004)$.

Discussion: Both the combination of atypical and typical antipsychotic medications and atypical medications are associated wi th the occurrence of abdominal obesity. The deposition of fat tissue in the abdomen negatively correlated with an ability to learn.

Conclusions: The future studies might explain the interactions between antipsychotic medications, obesity and cognitive function.

Keywords: metabolic disorders, memory, abstract reasoning

\section{Streszczenie}

Wstęp: Celem niniejszych badań było sprawdzenie czy kombinacja leków atypowych i typowych jest powiązana w takim samym stopniu z przemianą metaboliczną i funkcjami poznawczymi co leki z jednej grupy, to jest: atypowe, bądź typowe.

Materiał i metoda: Do badań włączono 91 dorosłych z diagnozą zaburzeń psychicznych (F-20-F69). Uczestnicy zostali podzieleni na grupy w zależności od rodzajów przyjmowanych leków: T+A (leki typowe i atypowe), A (leki atypowe), T (leki typowe), P (antydepresanty, środki uspokajające, leki normotymiczne / leki przeciwpadaczkowe). Do diagnozy funkcji poznawczych użyto testów: STMS, VFT, RAVLT.

Wyniki: Rodzaj przyjmowanych przez pacjentów leków nie różnicował grup pod względem BMI ( $<0,13)$, ani też w odniesieniu do ogólnego poziomu funkcji poznawczych $(\mathrm{p}<0,72)$ i fluencji słownej $(\mathrm{p}<0,34)$. Zarówno leki przeciwpsychotyczne atypowe, jak i połączenie leków atypowych i typowych były związane $\mathrm{z}$ występowaniem otyłości brzusznej $(\mathrm{p}<0,01)$. Wzrost obwodu talii zmniejszał zdolność do myślenia abstrakcyjnego $(p<0,005)$. Wskaźnik masy ciała, obwód talii korelował negatywnie z pamięcią odroczoną $(p<0,03, p<0,004)$.

Dyskusja: Zarówno kombinacja leków przeciwpsychotycznych atypowych i typowych jak i leki atypowe są związane z występowaniem otyłości brzusznej. Odkładanie się tkanki tłuszczowej w okolicy brzusznej koreluje negatywnie ze zdolnością do uczenia się.

Konkluzje: Niewątpliwie niezbędne są przyszłe badania wyjaśniające interakcje między lekami przeciwpsychotycznymi, otyłością a funkcjami poznawczymi.

Słowa kluczowe: przemiana metaboliczna, pamięć, myślenie abstrakcyjne.

\section{Introduction}

Overweight and obesity are one of the most important health problems in today's world. Growing food industry contributes to propagation of diets rich in fats and carbohydrates, and eating large portions of food [1]. According to the World Obesity Federation in the world, approximately 475 million adults are obese and more than twice of this number are overweight, what indicates that more than 1.5 billion people worldwide has the wrong body mass [2].
There are several definitions of overweight and obesity, which are largely based on the measurement of weight and height [3], and the most common is considered to be the one proposed by the World Health Organization (WHO). To determine obesity, it is necessary to calculate body mass index (BMI). This index is formed by dividing the body mass in kilograms by the square of the height specified in meters, (body mass $(\mathrm{kg}) /$ height $\left(\mathrm{m}^{2}\right)$. According to this indicator, the overweight status is recognized for people with BMI $\geq 25.00 \mathrm{~kg} / \mathrm{m}^{2}$, obesity from 
$\mathrm{BMI} \geq 30.0 \mathrm{~kg} / \mathrm{m}^{2}$, but underweight when the value of the index is less than $18.5 \mathrm{~kg} / \mathrm{m}^{2}$ [4].

Obesity brings with it a number of negative health consequences. Cardiovascular disease (mainly hypertension, heart disease and stroke), type 2 diabetes, diseases of the musculoskeletal system (e.g. osteoarthritis), and certain cancers (a.o. endometrial cancer, breast or colon cancer) are among the most potent risk factors of obesity [5].

It should be emphasized that the accumulation of fat in the abdomen is strongly associated with the risk of developing cardiovascular disease [6]. The easiest way to diagnose obesity is to measure waist circumference [7]. Because there are differences within the correct diagnosis of body mass depending on age, gender and ethnicity. Several methods of abdominal obesity identification were proposed, but the most often used are those proposed by the National Cholesterol Education Program - Adult Treatment Panel III NCEP-ATP III) and the International Diabetes Federation (IDF) [8], [9]. According to the NCEPATP III obesity is recognized when waist circumference in men is $\geq 102 \mathrm{~cm}$ and $\geq 88 \mathrm{~cm}$ in women. In contrast, according to the IDF's definition of abdominal obesity in white race, it is diagnosed when waist circumference is

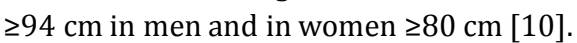

Persons suffering from mental disorders, including psychotic disorders, have greater tendency to have increased body mass [11]. Propensity for psychosis is influenced by several factors, including: specific diet and lifestyle, smoking and the effects of some psychotropic medications that cause mass gain [12]. The influence of the various medications on the body mass gain is varied. The largest increase is observed after the use of atypical antipsychotics medications, so-called new-generation, particularly such as clozapine and olanzapine. In terms of atypical antipsychotics medications, only those from the groups of molindone, ziprasidone, and aripiprazole do not cause mass gain. However, in the case of conventional medications, so-called first-generation antipsychotics, only those from the group of chlorpromazine cause mass gain [13].

It should be noted that the tendency to increased body mass was observed in psychiatric patients before taking antipsychotic treatment [14]. It is emphasized that there is a genetic predisposition of the mentally ill patients to excessive accumulation of body fat [15]. Obesity is strongly associated with cognitive impairment, which with age may lead to the formation of dementia [16]. Obesity can affect mental functions by changing plasticity of the brain, what may contribute to the development of cognitive and mood disorders [17].

In the present study, we attempted to examine the relationship between the cognitive impairment and the increased body mass, taking into account the types of the antipsychotics medications taken by the respondents.

\section{Material and methods}

We recruited 91 persons with mental disorders, participants of the Communal Home of Mutual Aid, the Occupational
Therapy Workshops and the staff of the District Vocational Rehabilitation Facility. Among the group, there were 48 people with schizophrenia (F-20), 3 with schizoaffective disorders (F25), 3 with persistent delusional disorder (F22), 7 with affective bipolar disorder (F31), 6 with depression (F32), 13 with neurotic disorders associated with stress and somatoform disorders (F40-F48), 11 with personality disorders and adult behavior disorder (F60-F69). Each person had to sign a voluntary consent to participate in research in accordance with resolution of the Medical University of Lublin Bioethics Committee (No KE-0254/101/ 2013).

The study consisted of two stages:

(1) Physical examination: Height, weight, waist circumference, hip circumference, calculation of BMI and abdominal obesity diagnosis according to the clinical IDF guidelines, clinical interview with the tested person concerning his/her career (co-existing diseases, medications, number of hospitalizations);

(2) Psychological tests: in order to diagnose cognitive functions. They were assessed using:

- a Short Test of Mental Status (STMS), used to measure cognitive functions, consisting of test of orientation trials (allo and autopsychic orientation), attention, learning, calculation, abstract reasoning, messages, drawings (constructional praxis), recall,

- Verbal Fluency Test (VFT), to examine the verbal semantic and categorical fluency,

- $\quad$ Rey Auditory Verbal Learning Test (RAVLT ) to assess short term memory, direct and delayed memory.

\section{Description of the group}

The study involved 91 participants (including 51 women and 40 men, mean age of patients was 46 years, the standard deviation $+/-13,3$ years). The group consisted of persons who were currently under constant psychiatric care. The exclusion criteria were: (1) substance abuse or dependence (2) a history of neurologic disorders (3) serious or unstable medical condition (i.e. poorly controlled hypertension, diabetes or coronary artery disease).

Because of the variety of taken medications, participants were divided into several groups according to defining features shown in Table 1. The largest group of participants (34\%) were receiving atypical antipsychotics medication (known as second generation antipsychotics), usually olanzapine, clozapine, amisulpride, risperidone, quetiapine, and sertindole, when it comes to $14 \%$ of participants, they were receiving typical antipsychotic medications (known as first generation antipsychotics), usually perazinum, haloperidol, while the other group (30\%) was taking both typical and atypical antipsychotic medications. The remaining $21 \%$ of participants were taking other medicines: antidepressants, sedatives, sleeping pills normothymic/antiepileptic.

\section{Statistical analysis}

The obtained results were statistically analyzed using STATISTICA software, version 10. 
Because of the lack of normality distribution of several variables, the study correlation between variables was carried out using a correlation coefficient of Spearman's rank. Due to the lack of normality distribution, testing hypotheses were performed using Mann-Whitney U test (comparing 2 groups). An analysis of the differences in the individual parameters was carried out using a Kruskal-Wallis test for independent trials, taking into account post hoc analysis (Dunn's Test). The results are shown in the charts using the median. The results were found to be significant at the level of $\mathrm{p}<0.05$.

\section{Results}

\section{Overweight and obesity}

Among all the investigated, overweight was found in 32 people (35\%), while in 27 (30\%) persons the correct

Figure 1. The BMI index and abdominal obesity according to the IDF guidelines in the group of women and men as measured in percentages.

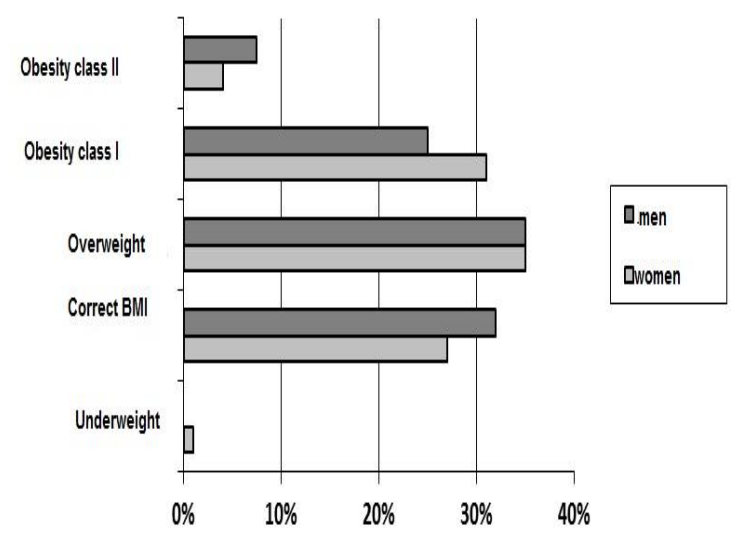

Figure 2.The body mass and the type of taken medications.

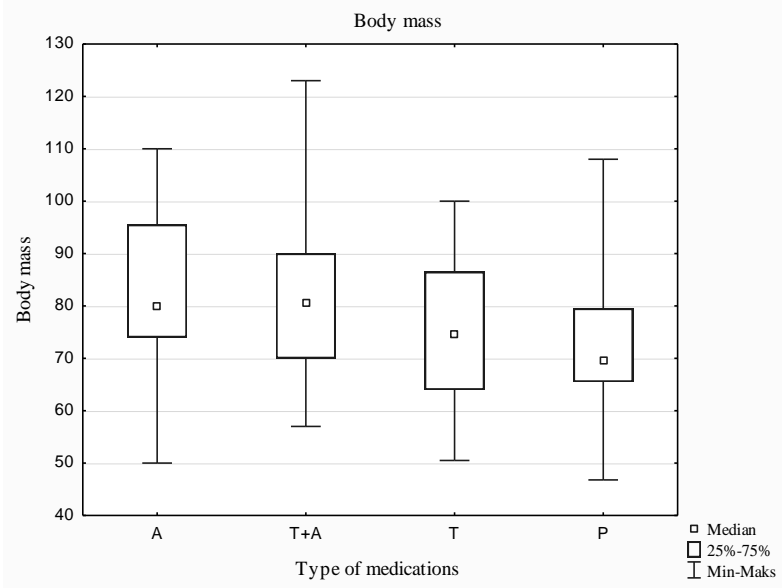

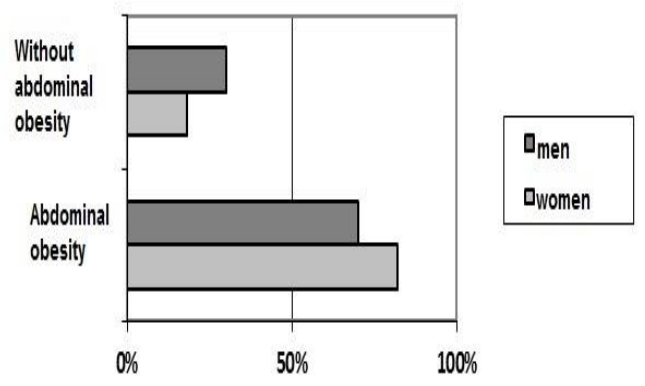

Figure 3. The waist circumference and the type of taken medications

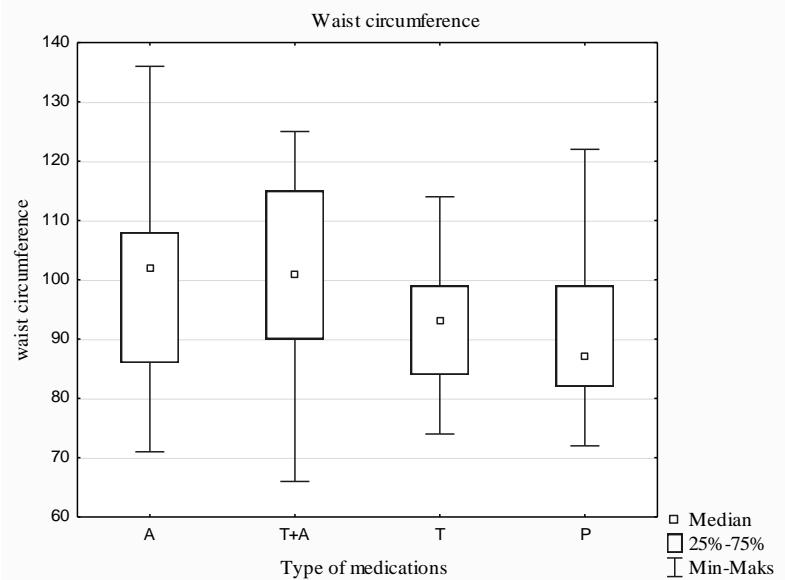

Figure 4. The BMI and the type of taken medications

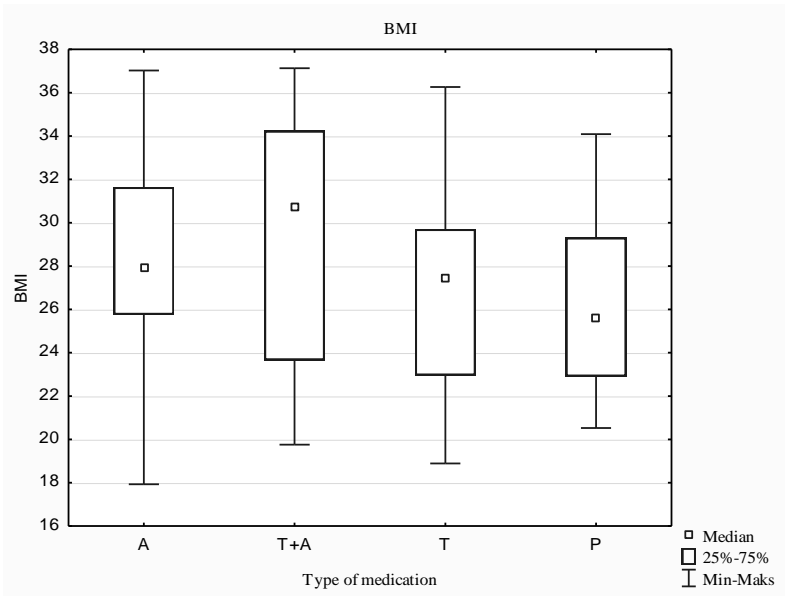


body mass was found (Figure 1.). Obesity class I was diagnosed in 26 patients (28\%), and obesity class II in 5 (5\%). One person was underweight (2\%). Abdominal obesity, according to IDF guidelines, was diagnosed in $70 \%$ of patients.

\section{Psychotropic medications vs. overweight and obesity}

The statistical analysis showed that the type of medications was associated with body mass, $p<0.03$, (Figure 2.). However, post hoc analysis indicated only the existence of certain tendency, particularly that people who did not take typical and atypical antipsychotics medicines (P) had lower body mass than persons taking both typical and atypical medications $(\mathrm{T}+\mathrm{A})$. Although, this tendency did not reach a level of statistical significance $(\mathrm{p}<0.08)$.

It has been noticed that the type of taken medications was also associated with the waist circumference, $\mathrm{p}<0.01$, (Figure 3.). Post hoc analysis showed that persons who were not taking typical and atypical antipsychotics medications (P) had lower waist circumference than persons taking atypical antipsychotics medications $(\mathrm{A}),(\mathrm{p}<0.04)$ and typical and atypical antipsychotics medications $(\mathrm{T}+\mathrm{A}),(\mathrm{p}<0.02)$. Medians were, respectively: $87(\mathrm{P}), 93(\mathrm{~T}), 101(\mathrm{~T}+\mathrm{A}), 102(\mathrm{~A})$. It was also found that BMI did not differ significantly in the various working groups, $\mathrm{p}<0.13$, (Figure 4.).

\section{Overweight and obesity, and cognitive functions}

Table 2. shows the correlations of Spearman's ranks between body mass indexes and waist circumference, and cognitive functions having regard to all the patients. The negative correlations were observed between several variables: age of patients and abstract thinking (rs -0.22, $\mathrm{p}<0.03$ ), age and direct memory ( $\mathrm{rs}-0.23, \mathrm{p}<0.02$ ), age of patients and delayed memory ( $\mathrm{rs}-0.29, \mathrm{p}<0.005$ ).

Body mass also showed a negative relationship with the memory, but only with the delayed one ( $r s-0.27, \mathrm{p}<0.005$ ). The body mass index, waist circumference correlated with the memory. In the case of the first variable, a relationship with the delayed memory was observed ( $r s-0.23, p<0.03$ ), in the case of the other two, both with the direct and delayed ones (rs 0.22 , $\mathrm{p}<0.03$ ), (rs $-0.36, \mathrm{p}<0.004$ ).

It has been shown that an increase in waist circumference measured in centimeters was connected with a decreased ability to abstract reasoning ( $r s-0.29, \mathrm{p}<0.005$ ).

It should be noted, that overall cognitive functions, which are the sum of all the subtests of STMS and the results in the VFT and RAVLT tests showed no statistically significant relationship.

In addition, it was shown that people with abdominal obesity did worse in the test measuring the delayed memory $(\mathrm{p}<0.04)$.

In order to investigate the impact of BMI on cognitive function, statistical analyses were made in three groups: overweight $(n=32)$, obesity class I $(n=26)$, correct BMI $(n=27)$. Because of the small number of persons with obesity class II $(n=5)$ and underweight $(n=1)$, they were were excluded. Analysis by means of Kruskal-Wallis test did not reveal any statistically significant differences between the BMI and cognitive functions in different groups $(\mathrm{p}>0.05)$.

\section{Discussion}

Persons suffering from mental disorders have greater tendency to overweight and obesity, what is caused by a number of factors, in particular, specific lifestyle and the negative effects of the antipsychotic treatment. As shown by studies of not yet treated patients, some diseases such as schizophrenia are closely associated with genetic predispositions to excessive depositing the adipose tissue [18], [19], [20], [21].

It shall be considered that 1 of 2 patients with schizophrenia is overweight [22]. As many as $68 \%$ of people treated for affective bipolar disease is overweight or obese and approximately $58 \%$ of people with heavier depression has obesity class I (BMI $\geq 30)$ [23]. In the own study, $68 \%$ of the total tested were overweight and obese,, and obesity was found in $32 \%$ of them.

There are several extensive studies checking the effects of antipsychotic, typical and atypical medications on body mass indexes. It is assumed that atypical medicines have a greater impact on body mass gain than typical medication [24].

In the group of 42,437 patients suffering from a variety of mental illnesses, it was shown that both typical and atypical medications can affect body mass gain. Interestingly, no statistically significant difference between them was observed [25]. In our study, it was shown that prescribed antipsychotics medications were related to body mass gain, but no significant differences between the various types of medications were observed.

Body mass gain in persons suffering from mental illness is associated with the use of psychotropic medications, with impaired sense of satiety, metabolic disorder and specific less active lifestyle. These factors affect the growth of fatty tissues in the abdomen, that is why patients taking atypical drugs are more exposed to abdominal obesity than persons taking typical medications [13].

The existing scientific reports indicate that persons with mental disorders, particularly suffering from schizophrenia, schizoaffective disorders, mood disorders, single and bipolar disorders, have greater tendency to deposit fat tissue in the abdominal area, and this tendency is further enhanced with antipsychotic medications [14], [26].

Statistical analysis showed that the atypical medication and combination of typical and atypical medication were related to the increase in waist circumference. It should be noted that, in relation to BMI, there were no differences between the particular groups. It follows from this that antipsychotic medicines may lead to a deposit of the particularly harmful fat abdomen, what contributes to the creation of cardiovascular diseases. Probably, more accurate taking into account lifestyle and health habits of patients, would give a fuller picture of this phenomenon.

The previous studies show, that atypical medications contribute to a significant improvement of cognitive function, in contrast to typical medications, which usually lead to deterioration of cognitive abilities [27], [28], [29]. 
Table 1. Groups divided by the types of taken medications.

\begin{tabular}{|c|c|c|}
\hline Division & Type of taken medications & Sample percentage \\
\hline $\mathrm{T}+\mathrm{A}$ & Typical and atypical antipsychotic medications & $27(30 \%)$ \\
\hline $\mathrm{T}$ & Typical antipsychotic medications & $14(15 \%)$ \\
\hline $\mathrm{A}$ & Atypical antipsychotic medications & $31(34 \%)$ \\
\hline $\mathrm{P}$ & $\begin{array}{c}\text { Other medicines: antidepressants, sedatives, sleeping pills } \\
\text { normothymic/antiepileptic }\end{array}$ & $19(21 \%)$ \\
\hline
\end{tabular}

Table 2. Correlation of Spearman's ranks between the BMI index, body mass, waist circumference and cognitive functions for all responders* - marked coordinates of correlation are significant at $\mathrm{p}<0.05$.

\begin{tabular}{|c|c|c|c|}
\hline & N - Important & R - Spearman & $\mathbf{p}$ \\
\hline *Age \& Abstract reasoning STMS & 91 & -0.2216 & 0.0347 \\
\hline *Age \& Direct Recall & 91 & -0.2339 & 0.0256 \\
\hline *Age \& Delayed Recall & 91 & -0.2872 & 0.0057 \\
\hline *Body mass \& Delayed Recall & 91 & -0.2719 & 0.0091 \\
\hline *BMI \& Delayed Recall & 91 & -0.2261 & 0.0311 \\
\hline $\begin{array}{l}\text { *Waist Circumference \& Abstract reasoning } \\
\text { STMS }\end{array}$ & 91 & -0.2883 & 0.0055 \\
\hline *Waist Circumference \& Direct Recall & 91 & -0.2248 & 0.0320 \\
\hline *Waist Circumference \& Delayed Recall & 91 & -0.3591 & 0.0004 \\
\hline
\end{tabular}

It is important to note that not only medicines affect the cognitive functions, but also the type of disorder is in this respect important. Psychotic mental disorders most seriously affect the deterioration in cognitive functions and these dependencies are becoming worse, especially with age, what refers to such diseases as schizophrenia or schizoaffective disorders [30], [31].

Many scientific reports indicate that obesity is a factor that leads to neurocognitive disorders [32], [33] and the latest results of the survey show that obesity leads to neurodegenerative diseases based on interferences in the white matter of the brain [34], [35], [36], [37], [38]. Research carried out on mice suggest that obesity leads to hippocampus function disorders, the structure responsible, inter alia, for learning and ability to learn [39].

Examining the relationship between cognitive functions and obesity in individuals with mental illness, the majority of correlations were detected in relation to memory processes. It was observed that both the increase in BMI, body mass and waist circumference negatively correlated with the delayed auditory memory and these dependencies increased along with the age of patients.

This is in line with other test results. Gunstad and co., in the group of 1703 people without mental disorders, demonstrated that abdominal obesity leads to cognitive impairment, including the disturbance of memory. The team noted that the increased mass leads to abnormalities in the verbal fluency and attentions, however such dependencies were not observed in the own study [32].

Spitznagel et al., in the group of 84 persons underwent bariatric surgery treatments and the assessment of cognitive functions before and after the surgery demonstrated that short-term memory is improving along with reduction in weight [40], what confirms the claim that obesity is closely linked with the deterioration of cognitive functions, but this process is to certain extent reversible.

By analyzing the study group, the relationship between abdominal obesity and the ability to abstract reasoning was observed, and these dependencies increased along with age and thus, with the duration of the disease. It should be noted that in most mental diseases, particularly those of psychotic ground, it comes to the deterioration of overall cognitive functions [41]. Abstract reasoning plays in this particular role, as according to some researchers, it is distorted in people with the first, untreated episode of the disease, next to learning capacity and attention [42].

By analyzing the study group, it should be noted that cognitive functions such as auditory memory, especially the delayed one and abstract reasoning, which showed the first relations with obesity, are first symptoms of dementia changes. According to recent scientific reports, obesity and changes caused by it lead to dementia vascular disorders and Alzheimer's disease [43].

The presented own research is not free from limitations. The group tested by us is diverse in terms of the type of disturbance and taken types of medications as well as their doses. Most of the research in this area does not take into account knowledge of patients on the subject and, consequently, the lifestyle of the patients. There is a need for research on a wider range taking into account these variables.

\section{Conclusions}

The implementation of atypical and combination of typical and atypical medications are associated with the occurrence of abdominal obesity, which carries with it a 
number of negative consequences such as cardiovascular disease, and diabetes type 2 . Obesity correlates with worsening of cognitive functioning, particularly, in the area of memory and abstract reasoning. It was observed that both the increase in BMI, body mass and waist circumference are negatively related to auditory delayed memory and these dependencies intensify along with age of patients. Future studies are needed in this area.

\section{Conflict of interest}

The authors have declared no conflict of interest.

\section{References:}

1. Department of Health, Government of South Australia 2006, http://www.health.sa.gov.au, (accessed 31 December 2015)

2. International Obesity Taskforce. IOTF: The Global Epidemic: IASO/IOTF analysis 2010. http://www.iaso.org/iotf/obesity /obesitytheglobalepidemic/ (accessed 31 December 2014)

3. Wąsowski M, Walicka M, Marcinowska-Suchowierska E. Obesity - definition, epidemiology, pathogenesis, Post Nauk Med. 2013(4):301-306

4. World Health Organization: The challenge of obesity in the WHO European Region. Fact sheet EURO 2005; 13: 1-4

5. World Health Organization: Obesity and overweight, 2014, http://www.who.int/mediacentre/factsheets/fs311/en/, (access 6 January 2015)

6. Despre's J-P. Abdominal obesity: the most prevalent cause of the metabolic syndrome and related cardiometabolic risk ,European Heart Journal Supplements. 2006; 8 (Supplement B), B4-B12, doi:10.1093/eurheartj/sul002)

7. National Heart, Lung, and Blood Institute's Expert Panel on the Identification, Evaluation, and Treatment of Overweight in Adults. Clinical guidelines on the identification, evaluation, and treatment of overweight and obesity in adults: executive summary. Am. J. Clin. Nutr. 1998; 68: 899-917

8. Executive Summary of The Third Report of The National Cholesterol Education Program (NCEP) Expert Panel on Detection, Evaluation, And Treatment of High Blood Cholesterol In Adults (Adult Treatment Panel III)., JAMA. 2001 16;285(19):2486-97

9. Alberti G, Zimmet PZ, Shaw J, Grundy SM. International Diabetes Federation 2006: The IDF consensus worldwide definition of the metabolic syndrome. http://www.idf.org/webdata/ docs/IDF_Meta_def_final.pdf, ( access 6 January 2015)

10. Cull CA, Jensen CC, Retnakaran R, Holman RR. Impact of the metabolic syndrome on macrovascular and microvascular outcomes in type 2 diabetes mellitus: United Kingdom Prospective Diabetes Study 78, Circulation. 2007; 6;116(19):2119-26

11. McElroy SL, Guerdjikova A, Kotwal R. Severe mental illness and obesity. In: Bermudes RA, Keck PE, McElroy SL, editors. Managing metabolic abnormalities in the psychiatrically ill: a clinical guide for psychiatrists. Arlington: American Psychiatric Publishing; 2006: 55-119

12. Newcomber JW, Antipsychotic medications: metabolic and cardiovascular risk, J Clin Psychiatry. 2007;68(4):8-13

13. Rzewuska M. Metabolic risk during antipsychotic treatment in patients with schizophrenia, Zaburzenia metaboliczne związane ze stosowaniem LPP u chorych na schizofrenię, Psychiatr Pol 2007; 41 (4):457-472
14. Ryan MC, Flanagan S, Kinsella U. The effects of atypical antipsychotics on visceral fat distribution in first episode, drug-naive patients with schizophrenia. Life Sci. 2004;74:1999-2008

15. Duda-Sobczak A., Wierusz-Wysocka B. Diabetes mellitus and psychiatric diseases, Cukrzyca a choroby psychiczne. Psychiatr Pol 2011; 45(4): 589-598

16. Elias MF, Elias PK, Sullivan LM, Wolf PA, D'Agostino RB. Lower cognitive function in the presence of obesity and hypertension: the Framingham heart study. Int J Obes Relat Metab Disord. 2003;27(2):260-268

17. Goodyer IM, Park, R.J, Herbert J. Psychosocial and endocrine features of chronic first-episode major depression in 8-16 year olds. Biological Psychiatry. 2001; 50(5):351-357

18. Berkowitz RI1, Fabricatore AN. Obesity, psychiatric status, and psychiatric medications. Psychiatr Clin North Am. 2011; 34(4):747-64

19. Wirshing DA. Schizophrenia and obesity: impact of antipsychotic medications. J Clin Psychiatry. 2004;65 (18):13-26

20. Monteleone P1, Martiadis V, Maj M. Management of schizophrenia with obesity, metabolic, and endocrinological disorders. Psychiatr Clin North Am. 2009;32(4):775-94

21. McElroy SL1, Kotwal R, Malhotra S, Nelson EB, Keck PE, Nemeroff CB. Are mood disorders and obesity related? A review for the mental health professional. JClin Psychiatry. 2004; 65(5):634-51, quiz 730

22. Mitchell AJ, Vancampfort D, Sweers K, van Winkel R, Yu W, and De Hert M. Prevalence of Metabolic Syndrome and Metabolic Abnormalities in Schizophreniaand Related Disorders-A Systematic Review and Meta-Analysis. Schizophrenia Bulletin 2011; 29: 1-13

23. De Hert M, Correll ChU, Bobes J, Cetkovich-Bakmas M, Cohen D, et al. Physical illness in patients with severe mental disorders. I. Prevalence, impact of medications and disparities in health care, Wolrd Psychiatry 2011; 10(1):52-77

24. Joseph A. Lieberman. Metabolic Changes Associated With Antipsychotic Use, Prim Care Companion J Clin Psychiatry. 2004; 6(2): 8-13

25. Sicras-Mainar A, Navarro-Artieda R, Rejas-Gutiérrez J, BlancaTamayo M. Relationship between obesity and antipsychotic drug use in the adult population: A longitudinal, retrospective claim database study in Primary Care settings, Neuropsychiatr Dis Treat. 2008; 4(1): 219-226

26. Zhao G, Ford ES, Li Ch, Tsai J, Dhingra S, Balluz LS. Waist circumference, abdominal obesity, and depression among overweight and obese U.S. adults: national health and nutrition examination survey 2005-2006, BMC Psychiatry 2011,http://www.biomed central.com /1471-244X/11/130, (access 16 January 2015)

27. Woodward ND, Purdon SE, Meltzer HY, Zald DH. A meta-analysis of neuropsychological change to clozapine, olanzapine, quetiapine and risperidone in schizophrenia. Int J Neuropsychopharmacol 2005; 8:457-72

28. Lis S, Krieger S, Gallhofer B,Torre P, Mittoux A, Menard F. Sertindole is superior to haloperidol in cognitive performance in patients with schizophrenia: A comparative study. Eur Neuropsychopharmacol 2003;13(4):323-324

29. Minzenberg MJ, Poole JH, Benton C, Vinogradov S. Association of anticholinergic load with impairment of complex attention and memory in schizophrenia. Am. J. Psychiatry 2004; 161:116-124

30. Capleton R Cognitive function in schizophrenia: association with negative and positive symptoms. Psychol Rep. 1996; 78: 123-128

31. O'Leary D, Flaum M, Kesler M, Flashman L, Arndt S, Andreasen NC Cognitive correlates of the negative, positive, and psychotic symptom dimensions in schizophrenia. J Neuropsychiatry Clin Neurosci. 2000; 12: 4-15 
32. Gunstad J, Paulb RH, Cohenb RA, Tateb DF, Spitznagelc MB, Gordon E. Elevated body mass index is associated with executive dysfunction in otherwise healthy adults. Comprehensive Psychiatr., 2007; 48: 57-61

33. Alosco ML1, Spitznagel MB, Gunstad J. Obesity as a risk factor for poor neurocognitive outcomes in older adults with heart failure. Heart Fail Rev. 2014; 19(3):403-11

34. Stanek KM, Grieve SM, Brickman AM, Korgaonkar MS, Paul RH, Cohen RA, Gunstad JJ. Obesity is associated with reduced white matter integrity in otherwise heal thy adults. Obesity. 2011; 19: 500-504

35. Gustafson D, Steen B, Skoog I. Body mass index and white matter lesions in elderly women. An 18-year longitudinal study. Int Psychogeriat. 2004; $16: 327-36$

36. Rahmouni K, Correia ML, Haynes WG, Mark AL. Obesityassociated hypertension: new insights into mechanisms. Hypertension. 2005;45:9-14

37. Gustafson D, Lissner L, Bengtsson C, Bjorkelund C, Skoog I. A 24year follow-up of body mass index and cerebral atrophy. Neurology. 2004; 63:1876-81

38. Gazdzinski S, Kornak J, Weiner MW, Meyerhoff DJ. Body mass index and magnetic resonance markers of brain integrity in adults. Ann Neurol. 2008;63(5):652-7

39. Roy A, Jana M, Corbett GT, Ramaswamy S, Kordower JH, Gonzalez FJ, Pahan K. Regulation of CREB and hippocampal plasticityrelated genes by peroxisome proliferator-activated receptor $\alpha$, Cell Rep. 2013; 4(4): 724-737.

40. Spitznagel MB, Garcia S, Miller LA, Strain G, Devlin M, Wing R, Cohen R, Paul R, Crosby R, Mitchell JE., Gunstad J, Cognitive Func- tion Predicts Weight Loss Following Bariatric Surgery, Surg Obes Relat Dis. 2013; 9(3): 453-459

41. Levy B., Manove E. Functional Outcome in Bipolar Disorder: The Big Picture, Depression Research and Treatment, 2012; (2012):1-12

42. Trivedi JK. Cognitive deficits in psychiatric disorders: Current status, Indian J Psychiatry. 2006; 48(1): 10-20

43. Gustafson DR, Bäckman K, Joas E, Waern M, Östling S, Guo $\mathrm{X}$, Skoog I. 37 years of body mass index and dementia: observations from the prospective population study of women in Gothenburg, Sweden. J Alzheimers Dis. 2012;28(1):163-71

\section{Correspondence address}

Urszula Łopuszańska, MA

Department of Applied Psychology

Medical University of Lublin

Chodzki 15 Street

20-093 Lublin, Poland

Phone +48814486600

urszula.lopuszanska@umlub.pl

Otrzymano: 05.10.2017

Zrecenzowano: 02.12.2017, 19.12.2017

Przyjęto do druku:21.12.2017 